\title{
Effectiveness of Some Biotic and Abiotic Agents to Control Tomato Early Blight Disease Caused by Alternaria solani.
}

\author{
Khalil, M.E.K.I. and Adbelghany, R.E.A.
}

Received: 23 March 2021 / Accepted: 09 May 2021 / Published online: 19 May 2021. CEgyptian Phytopathological Society 2021

\begin{abstract}
Bacillus megaterium, Bacillus subtilis, Pseudomonas fluorescens, Trichoderma harzianum, Trichoderma album and Trichoderma viride isolates, as well as different concentrations of chemical inducers, such as chitosan and salicylic acid were evaluated against Tomato early blight, under laboratory and greenhouse conditions. Under laboratory conditions, all tested bio agents, as well as the different concentrations of the tested chemical inducers, decreased the linear growth of $A$. solani, as the inhibition of fungal growth was increased by increasing the concentration of both chemical inducers in the growing medium. The chemical inducer chitosan at a concentration of $4.0 \mathrm{mg} / \mathrm{mL}$ PDA medium, caused the highest inhibition of linear growth of the fungus, followed by anti-fungus $T$. harzianum. When, different concentrations of chitosan and salicylic acid were tested on spore germination of $A$. solani, a concentration of $4.0(\mathrm{mg} / \mathrm{mL})$, for chitosan and a concentration of 25.0 (mM), for salicylic acid were the best concentrations used to reduce the spore germination of $A$. solani. Under greenhouse conditions, spraying tomato plants (cv. Super Strain B hybrid), with any of the tested biological agents as well as different concentrations of both the chemical inducers before infection of tomato plants by A. solani reduced the severity of early blight, in addition, to increase the fresh and dry weight of tomato plants. The chemical inducer chitosan at a concentration of $4.0(\mathrm{mg} / \mathrm{mL})$, caused the highest decrease of the disease severity, and the highest increase in fresh and dry weight of tomato plants, followed by the bio agent T. harzianum. The activities of defense-related enzymes i.e., polyphenoloxidase, peroxidase and chitinase were significantly increased in all treated plants with the tested biotic and abiotic agents. Chitosan at a concentration of $4.0(\mathrm{mg} / \mathrm{mL})$ resulted in the highest activity of oxidative enzymes, followed by T. harzianum. Meanwhile, the total content of phenols was higher in treated plants than in the untreated ones. The tested bio agents and chemical inducers might be playing an important role in management of tomato early blight through induction of induced systemic resistance.
\end{abstract}

Key words: Tomato, Early blight, Alternaria solani, Biological control, Chemical inducer.

*Correspondence: Khalil, M.E.K.I.

E-mail: mohamedeffat631@gmail.com

Mohamed E.K.I. Khalil

Rady E.A. Adbelghany

Plant Pathology Research Institute, Agricultural Research Center, 12619, Giza, Egypt.

\section{INTRODUCTION}

Tomato (Lycopersicon esculentum Mill.) is one of the most widespread and popular vegetables in the world. It ranks second in economic importance after the potato in many countries (Prajapati et al., 2014). It is one of the crops that gives a high financial return to many farmers in most parts of the world, as it can be marketed fresh or manufactured (Anonymous, 2016). The tomato early blight caused by the fungal Alternaria solani is the most economically important tomato disease in most parts of the world, including the Caribbean (Ali et al., 2016). Infection of tomato plants by the fungus that causes early blight can lead to great losses in crop yield due to damaging leaves and fruits (Chaerani et al., 2007 and EL-Tanany et al., 2018). Weather conditions are an important factor in causing this disease and it can spread in a wide range of climatic conditions, but it is widely spread in areas of rain and high relative humidity (Moustafa et al., 2018a). Generally, the use of fungicides in controlling plant diseases is still one of the most effective processes used, but the uncontrolled use of these substances in agriculture in many regions of the world raised serious concerns about health issues, and environmental pollution in particular, after it was published (Carson 1962). In addition, many fungi can develop resistance races for most of the fungicides used, (Chaerani et al., 2007 and Ramkissoon, et al., 2016). Under the aforementioned conditions, it becomes imperative to develop plant-derived plant-based pesticides or microbial pesticides, whether biological, environmentally friendly or biodegradable, in order to control plant pathogens. Biotic and abiotic inducers have potential in agriculture with regard to control plant diseases (Anand et al., 2009a and Simonetti et al., 2012). Currently, biological control using antimicrobials, resistance 
promoters and growth promoters offers an excellent practical and economical alternative in controlling plant pathogens (Chandrashekara et al., 2012 and EL-Tanany et al., 2018). Epiphytic microbes have been documented for numerous phyllosphere and rhizosphere inhabiting organisms and/or stimulating the induction of systemic resistance mechanisms within the plant (Bargabus et al., 2002). Recently, the induction of plant resistance by application of several microorganisms or organic materials has emerged as a new strategy in the management of plant diseases (Rais et al., 2017). Biotic inducers are known to have eliciting activities leading to a variety of defense reactions in host plants in response to microbial infection, including the defense related enzymes and accumulation of phenolic compounds as well as specific flavonoids (Govindappa et al., 2010; Esh et al., 2011; Abd El-Rahman et al., 2012; Hussein et al., 2018 and Sarhan et al., 2018). Recently, researchers have turned to activate the systemic induced resistance (SIR) of plants using some chemical inducers, for example, chitosan and salicylic acid, as these substances enhance the same physiological and biochemical changes in plants as do systemic active biological resistance (El-mohamedy et al., 2015; Ramkissoon et al., 2016 and Moustafa et al., 2018b). Moreover, (ChunYan et al., 2003 and Atia 2005), found that treating tomato plants with chitosan at a rate of $(1 \mathrm{mg} / \mathrm{mL})$ a week before the plant was infected with the fungi Phytophthora infestans and Alternaria solani led to plant disease resistance to those fungi where the (SIR) activity of tomato was stimulated in four leaves of the seedlings. The activity of defence related enzyme $\beta-1,3$ glucanase is known to be as an inducer of systemic resistance of many infected plants with fungal pathogens (Saikia, et al., 2005 and Govindappa, et al., 2010). Also, this enzyme acts synergistically in the partial degradation of fungal cell walls. Moreover, a parallel increase in the activities of these enzymes is important for optimal function in plant defense (Saikia, et al., 2005). Also, peroxidase (PO), phenylalanine ammonia-lyase (PAL) and polyphenoloxidase (PPO) enzymes were mentioned as elicitors of the induced systemic resistance (ISR) in plant disease control (Yasmin, et al., 2016). These enzymes act as elicitors of phenylpropanoid pathway, resulting in the biosynthesis of a diverse array of plant metabolites such as, phenolic compounds, flavonoids, tannins and lignin. These products can provide defense in plants against pathogenic attack (Hahlbrock and
Scheel, 1989). Many studies indicated to greater accumulation of phenolics as a result of increasing the activities of these oxidative enzymes which could offer the protection against plant diseases (Singh et al., 2003; Abd El-Rahman et al., 2012 and Hussein et al., 2018).

This work aims to evaluate the effectiveness of some biotic and abiotic agents to control early blight of tomatoes under greenhouse conditions, in addition to estimating some of the biochemical response in treated plants, which is related to activating the systemic induced resistance.

\section{MATERIALS AND METHODS}

\section{1- Source of the fungal pathogen, the antagonistic agents and the tomato seeds:}

The fungus Alternaria solani was isolated from tomato plants (cv. Super Strain B), with obvious early blight symptoms, collected from Qaliobia Governorate. The fungus was then purified and identified according to its morphological features using the descriptions of Singh (1982) and Barnett and Hunter (1987). Pure cultures of the pathogen were maintained on PDA slants and stored at $4{ }^{\circ} \mathrm{C}$ till used.

\section{2- Biotic and Abiotic agents used in Induction of Systemic Induced Resistance in Tomato:}

Biotic agents included pure isolates of six antagonists i.e., three bacterial isolates namely Bacillus megaterium, Bacillus subtilis, Pseudomonas fluorescens, and three fungal isolates namely Trichoderma harzianum, Trichoderma album and Trichoderma viride, were obtained from Integrated Pest Management Department (IPMD), Plant Pathology Institute, Agricultural Research Center, Giza, Egypt. The Pure cultures of the fungal bio agents were maintained on PDA slants whereas, cultures of bacterial biogents tested were maintained on nutrient agar slants. Both fungal and bacterial cultures were Kept at $4^{\circ} \mathrm{C}$ until their use.

Abiotic materials used in the experiment were Chitosan with different concentrations $(1.0,2.0,3.0$ and $4.0 \mathrm{mg} / \mathrm{mL})$ Salicylic acid of $1.0,5.0,10.0$, and $25.0 \mathrm{mM}$ concentrations to clarify their effects as inducers of systemic resistance in tomato plants against early blight infection.

\section{3- Tomato seeds tested:}

Tomato seeds (cv. Super Strain B hybrid) were kindly provided from Horticulture Research Institute., Agricultural Research Center, Giza, Egypt. 


\section{4- Laboratory experiments:}

\section{1- Efficacy of some antagonistic bacterial and fungal agents on linear growth of Alternaria solani in vitro:}

The anti-bacterial effect of the tested bacterial isolates i.e., Bacillus megaterium, Bacillus subtilis, Pseudomonas fluorescens and the antifungal effect of each of Trichoderma harzianum, Trichoderma album and Trichoderma viride on the growth of the tested fungal pathogen $A$. solani were studied under laboratory conditions. Petri dishes $(9 \mathrm{~cm}$ in diameter) containing PDA medium were inoculated by streaking a line of each antibacterial separately at a distance of $2 \mathrm{~cm}$, from the edge of the dish, all dishes were incubated at $28 \pm 1^{\circ} \mathrm{C}$ for $24 \mathrm{~h}$. Then a fungal disc ( $5 \mathrm{~mm}$ ) of $A$. solani taken from the edges of a seven-day-old culture was placed at the same distance from the edge of the plate against the bacterial line. As for antagonistic fungi, the plates were inoculated with disc $(5 \mathrm{~mm}$ in diameter) of each fungal isolate at a distance of $2 \mathrm{~cm}$ from the edge of the plates against the pathogen, which was placed at the same distance from the edge of the plate. Petri dishes inoculated with $A$. solani alone as a comparison treatment. All dishes were incubated at $27 \pm 1^{\circ} \mathrm{C}$. Three replicate dishes were used for each treatment. The percentage of fungal growth reduction in the different treatments was calculated when the pathogen growth was completed in one of the comparison treatments plates. Inhibition ratio was calculated in all treatments according to Fokkema, (1973).

\section{2-Efficacy of different concentrations of chitosan and salicylic acid on linear growth of Alternaria solani in vitro:}

This experiment was designed to investigate the inhibitory effect of the tested chemical inducers for example chitosan $\left(\mathrm{C}_{12} \mathrm{H}_{24} \mathrm{~N}_{2} \mathrm{O}_{9}\right)$ and salicylic acid $\left(\mathrm{C}_{7} \mathrm{H}_{6} \mathrm{O}_{3}\right)$ on the linear growth of A. solani on PDA medium with streptomycin sulfate $(300 \mathrm{mg} / \mathrm{L})$. The chemical catalysts used were tested at four concentrations as follows:

Stock solutions (10 mg/mL), $2 \mathrm{~g}$ of high molecular weight chitosan (viscosity $=800$ $2000 \mathrm{cps}$ and $>75 \%$ deacetylation) were prepared by dissolving them in $100 \mathrm{~mL}$ of distilled water with $2 \mathrm{~mL}$ of acetic acid (stirred for $24 \mathrm{~h}$ ), and the volume was taken up to 200 $\mathrm{mL}$ with distilled water. The $\mathrm{pH}$ was adjusted to 5.6 with the addition of sodium hydroxide $1.0 \mathrm{~N}$ (El- Ghaouth et al.,1991). The chitosan solution was sterilized for 15 minutes in an autoclave at1.5 lb. Corresponding aliquots were taken to obtain different concentrations of chitosan (1.0, 2.0, 3.0 and $4.0 \mathrm{mg} / \mathrm{mL}$ ).

Salicylic acid was tested at concentrations of 1.0, 5.0, 10.0, and $25.0 \mathrm{mM}$. The corresponding aliquots were taken from a $1 \mathrm{M}$ stock solution in sterile distilled water.

The desired quantities of tested promoters were added to sterile and molten PDA medium to achieve the tested target concentrations. For each compound, a $10 \mathrm{~mL}$ aliquots of modified PDA medium were aseptically poured into a Petri dish $(9 \mathrm{~cm}$ in diameter), with an unmodified PDA dish used as a comparison treatment. A $5 \mathrm{~mm}$ agar disc bearing the growth of the pathogen $A$. solani was transferred to the test medium. Three duplicate dishes were used for each treatment. Then all dishes were incubated at $27 \pm 1^{\circ} \mathrm{C}$. Colony diameters were measured when the comparison treatment surfaces in Petri dishes were covered with fungal growth.

4.3-Efficacy of different concentrations of chitosan and salicylic acid on spore germination of Alternaria solani in vitro:

The effect of different concentrations of chitosan and salicylic acid was studied using the slide technique described by Nair and Ellingboe, (1962). A. solani inoculum was prepared by growing on $\mathrm{V} 8$ juice agar-CaCO3 media $6.5 \mathrm{pH}$, at $25 \pm 1^{\circ} \mathrm{C}$, with alternating 12 -hour periods of light and darkness for seven days (Rodrigues et al. 2010). Then $10 \mathrm{~mL}$ of sterile distilled water were added to each dish and the colonies were carefully scraped with a sterile needle. The resulting conidial suspension was adjusted to $\left(1 \times 10^{5}\right.$ spore $\left./ \mathrm{mL}\right)$. The different concentrations of the chemical inducers were prepared as previously mentioned. A drop of each concentration was placed individually on a clean, sterile dried glass slide as a film, and then $0.1 \mathrm{~mL}$ of the suspended spore of $A$. solani was placed on top of this film using a sterile pipette. A drop of sterile distilled water was placed on another sterile glass slide and mixed with the fungus spores suspension, where it was used as a comparison treatment. Three replicates were used for each treatment. Each slide was placed on a U-shaped glass rod in a wet chamber composed of a sterile Petri dish lined with filter paper impregnated with sterile distilled water. All Petri dishes were incubated at $27 \pm 1^{\circ} \mathrm{C}$ for 24 hours prior to assay. Spore germination percentage was calculated. 


\section{5- Greenhouse experiments:}

5.1- Effect of treating tomato plants with biotic agents and different concentrations of abiotic inducers on systemic induced resistance of tomato against Tomato early blight (disease severity) as well as on plant fresh and dry weight (g/plant) under artificial infection with Alternaria solani in vivo:

The two potted experiments were designed under greenhouse conditions, in Plant Pathology Research Institute, Agricultural Research Center, Giza, Egypt to study the effect of antagonistic bacterial isolates (B. megaterium, B. subtilis and Ps. fluorescens) and antagonistic fungal isolates (T. harzianum, T. album and $T$. viride), also to investigate the efficacy of different concentrations of two chemical inducers (chitosan and salicylic acid) on the severity of tomato early blight caused by $A$. solani, as well as fresh and dry weight ( $\mathrm{g} / \mathrm{plant})$ of tomato plants. In this experiment, $25 \mathrm{~cm}$ of plastic pots were used, each contained $5 \mathrm{~kg}$ of sandy loam soil. Five tomato transplants (cv. Super Strain B hybrid), 4-5 weeks old containing 4-5 whole real leaves, were transplanted in each pot, and five pots were used as replicates per each treatment in addition to the untreated control of each experiments. The two experiments were designed as complete randomized block design. Antagonistic bacterial suspensions were prepared at a rate of $\left(2.8 \times 10^{8} \mathrm{cfu} / \mathrm{mL}\right)$ for each of treatment. Meanwhile, spore suspensions of fungal bioagents were prepared at a rate $\left(2.5 \times 10^{5}\right.$ spore $/ \mathrm{mL}$ ) for each one, according to ELTanany et. al. (2018). Tomato plants were sprayed with spore suspensions of each of the six tested bioagents individually once every two weeks. On the other experiment, tomato plants were sprayed every two weeks individually with either chitosan at a concentration of $(1,2,3$ and $4 \mathrm{mg} / \mathrm{mL})$, or salicylic acid at concentrations (1, 5,10 , and $25 \mathrm{mM}$ ). After $48 \mathrm{hr}$. all tomato plants treated either by bio agents or abiotic chemicals were sprayed once with spore suspension $\left(1 \times 10^{5}\right.$ spore $/ \mathrm{mL}$ ) of $A$. solani, using a manual spraying machine for all treatments. Tomato plants received all the recommended normal agricultural practices except that the greenhouse floor was sprayed with water early in the morning to provide adequate air humidity. Disease severity\% was recorded two weeks after artificial inoculation with the tested pathogen, using a scale consisted of six categories ranging from 0 to five $(0=$ no infection, $1=$ scattered spots of infection less than $10 \%$ of the leaf area, $2=$ more than $10 \%>20 \%, 3=20 \%>30 \%, 4=$ $30 \%>40 \%$ and $5=<40 \%$ of the leaf area, then disease severity was calculated using the formula developed by Townsend \& Heuberger, (1943).

$$
\text { DS }(\%)=\boldsymbol{\Sigma}(\mathbf{n V}) / \mathbf{N V} \times \mathbf{1 0 0}
$$

Where, $\mathrm{n}$ - degree of infection according to the scale; $\mathrm{v}$ - number of samples per each category; $\mathrm{V}$ - total number of samples examined; $\mathrm{N}$ - the highest score of the categories.

Then efficacy of biological control agents and different concentrations of chemical inducers was calculated using Abbott's formula (Abbott, 1925) as follows:

$$
\text { Efficacy }(\%)=(X-Y) / X \times 100
$$

Where, $X=$ disease severity in untreated control. $\mathrm{Y}=$ disease severity in each treatment

Also, some growth parameters i.e., fresh and dry weight $\mathrm{g} /$ plant of shoot and root of tomato plants were recorded.

\section{2- Estimation of enzyme activity and total phenols:}

Treated and untreated, tomato leaf samples (cv. Super Strain B hybrid), were collected 48 hr. after each treatment every two weeks and at the end of the experiments. Leaf samples were ground using a $0.2 \mathrm{M}$ TrisHCl buffer $(\mathrm{pH} 7.8)$ containing $14 \mathrm{mM}$-mercaptoethanol at the rate $1 / 3 \mathrm{w} / \mathrm{v}$. The extracts were centrifuged at 10,000 $\mathrm{rpm}$ for $20 \mathrm{~min}$ at $4^{\circ} \mathrm{C}$. The supernatant was used to estimate the activity of polyphenoloxidase, peroxidase and hydrolytic enzymes (chitinase), according to the method described by Tuzun et al. (1989).

\subsection{1- Determination of polyphenol oxidase activity:}

Polyphenol oxidase activity was determined according to the method described by Maxwell and Bateman (1967). In the beginning, an amount of crude enzyme $(0.5 \mathrm{~mL})$ was mixed with sodium phosphate buffer $(\mathrm{pH} 7)$ and then $0.5 \mathrm{~mL}$ of catechol was placed and mixed together and finally completed the total volume to be $3 \mathrm{~mL}$ using sterile distilled water. Polyphenoloxidase activity was expressed by the change in absorbance at the optical density of $495 \mathrm{~nm}$ min-1 g-1 on a fresh weight, using a spectrophotometer.

\subsection{2- Estimate peroxidase activity:}

Peroxidase activity was estimated according to Allam and Hollis (1972). In this method, the oxidation of pyrogallol was calculated and converted to pyrogalline in the presence of $\mathrm{H}_{2} \mathrm{O}_{2}$ at a wavelength of $425 \mathrm{~nm}$. The peroxidase enzyme activity was differentiated as the change 
in absorption at $425 \mathrm{~nm} / \mathrm{min}-1 \mathrm{~g}-1$ on a fresh weight using a spectrophotometer.

\subsection{3- Estimation of chitinase activity:}

Chitinase activity was determined according to the method described by Ried and OgrydZiak (1981). Enzyme activity was characterized as $\mu$ moles $\mathrm{N}$-acetylglucosamine (NAG) $\mathrm{g} / \mathrm{mL}$ at $575 \mathrm{~nm}^{-1} \mathrm{~g}^{-1}$ fresh weight of tissue using a spectrophotometer.

\subsection{4- Estimation of total phenols content:}

Total phenols extract was obtained from treated tomato seedlings growing under greenhouse conditions as described by Hsu et al. (2003). A 5gm extract sample was taken from every treatment, and it was mixed up with 80 $\mathrm{mL}$ methanol and kept overnight. The solution was filtered through four layers of cheesecloth and the product was diluted to $100 \mathrm{~mL}$ (Slinkard and Singleton), (1997). A volume of the prepared solution was taken and mixed with 1.4 $\mathrm{mL}$ of distilled water, and $0.1 \mathrm{~mL}$ of $50 \%$ (1N) Folin-Ciocalteu phenol reagent. After of time period at least 30 seconds and not exceeding 8 minutes, the chemical substance (sodium carbonate $20 \%$ ) was added at $0.3 \mathrm{~mL}$ w/v. Then, the mixture was left for 2 hours until it could complete the reaction and after vortexing for a short time, the color and the change in absorbance was estimated at $765 \mathrm{~nm}$. The total dissolved phenol content was standardized against tannic acid and the values of the change in absorbance were converted to $\mathrm{mg}$ of phenols per 100 grams of fresh weight tissue.

\section{6- Statistical analyzes:}

The results obtained for appropriate statistical analysis were set using the MSTAT-C program (MSTAT-C, 1991), while the means were compared using ANOVA where LSD $(\mathrm{P} \leq 0.05)$.

\section{RESULTS}

\section{1- Laboratory experiments:}

\section{1- Efficacy of some antagonistic bacterial} and fungal agents on linear growth of Alternaria solani in vitro:

The inhibitory effect of the tested six bio agents i.e., B. megaterium, B. subtilis, Ps. fluorescens, T. harzianum, T. album and $T$. viride against $A$. solani fungal growth is shown in Table (1). The tested bio agents were classified into three groups according to their efficacy against the fungal growth of $A$. solani. The first group contained the fungal bio agents $T$. harzianum and $T$. viride, which gave the highest inhibition efficacy against A. solani growth, being, 97.06 and $85.30 \%$, respectively, while the second group contained the bacterial bio agents $B$. megaterium and $B$. subtilis, which gave a moderate decrease in the growth of the fungus, being 67.53 and $60.30 \%$, respectively. On the other hand, the lowest inhibition was given by the bio agents $T$. album and $P s$. fluorescens. The corresponding mean values were 53.01 and $39.19 \%$, respectively, which ranked in the third group. The obtained results (Table,1) indicate that $T$. harzianum was the best bio agent which inhibited the fungal growth of A. solani, while T. album was the least effective one in this respect.

Table (1): Efficacy of some antagonistic bacterial and fungal agents on growth inhibition of Alternaria solani.

\begin{tabular}{lc}
\hline \multicolumn{1}{c}{ Bio agents } & Inhibition \% \\
\hline Bacillus megaterium & 67.53 \\
Bacillus subtilis & 60.30 \\
Pseudomonas fluorescens & 53.01 \\
Trichoderma harzianum & 97.06 \\
Trichoderma album & 39.19 \\
Trichoderma viride & 85.30 \\
Control & 0.00 \\
\hline L.S.D at 0.05 & 3.09 \\
\hline
\end{tabular}

1.2-Efficacy of different concentrations of chitosan and salicylic acid on linear growth and spore germination of Alternaria solani:

Data in Table (2) indicate that all the tested concentrations of chemical inducers, i.e., chitosan and salicylic acid reduced both linear growth and spore germination of $A$. solani compared to the untreated control. Inhibition rates were increased with increasing the concentration of both chemical inducers. Concentrations of 3 and $4 \mathrm{mg} / \mathrm{mL}$ of chitosan, as well as $25 \mathrm{mM}$ of salicylic acid, were the most effective treatments in inhibiting the linear growth of $A$. solani, which gave complete inhibition of $A$. solani growth. Whereas the concentrations of $1 \mathrm{mg} / \mathrm{mL}$ of chitosan and $5 \&$ $1 \mathrm{mM}$ of salicylic acid were the least efficient ones against $A$. solani growth giving 2.3, 2.7 and $6.5 \mathrm{~cm}$, respectively. Moreover, the chemical inducers were tested on spore germination rate of A. solani. The obtained results (Table, 2) indicate that the concentrations $4 \mathrm{mg} / \mathrm{mL}$ and 25 $\mathrm{mM}$ of chitosan and salicylic acid, respectively, gave the same trend of the results that were mentioned when applying these concentrations to the linear growth of the tested fungus. 
Concentrations of $3 \& 4 \mathrm{mg} / \mathrm{mL}$ of chitosan gave complete inhibition of spore germination $(0.0 \%)$. The lowest percentage of spore germination $(16.6 \%)$ was obtained when chitosan was used at $3 \mathrm{mg} /$ whereas, the concentration of $25 \mathrm{mM}$ of salicylic acid gave the lowest percentage of spore germination (1.0\%). Moreover, the first concentration (1.0) of chitosan and salicylic acid was the least effective in reducing spore germination (23.3 and $50.0 \%$, respectively). Generally, chitosan was more efficient in reducing mycelia growth and spore germination rate of $A$. solani than salicylic acid.

Table (2): Efficacy of different concentrations of chitosan and salicylic acid on linear growth $(\mathrm{cm})$ and spore germination $\%$ of Alternaria solani.

\begin{tabular}{cccc}
\hline $\begin{array}{c}\text { Chemical } \\
\text { inducers }\end{array}$ & Concentration & $\begin{array}{c}\text { Linear } \\
\text { growth } \\
(\mathrm{cm})\end{array}$ & $\begin{array}{c}\text { Spore } \\
\text { germination } \\
(\%)\end{array}$ \\
\hline & 1 & 2.3 & 23.3 \\
Chitosan & 2 & 1.4 & 16.6 \\
$(\mathrm{mg} / \mathrm{mL})$ & 3 & 0 & 0 \\
& 4 & 0 & 0 \\
\cline { 2 - 4 } & Mean & 0.93 & 9.98 \\
\hline Salicylic acid & 1 & 6.5 & 50 \\
$(\mathrm{mM})$ & 10 & 2.7 & 33.3 \\
& 25 & 1.2 & 26.6 \\
\cline { 2 - 4 } Control & Mean & 0 & 1 \\
\hline LSD at 0.05 & - & 2.60 & 27.73 \\
& & \multicolumn{2}{c}{ Inducers $(\mathrm{I})=0.7$} \\
& & \multicolumn{2}{c}{ Conc. $(\mathrm{C})=2.4$} \\
\hline
\end{tabular}

2- Greenhouse experiments:

2.1- Effect of treating tomato plants with biological control agents and different concentrations of some chemical inducers on severity of tomato early blight as well as fresh and dry weight (g/plant):

2.1.1- The effectiveness of some antagonistic bacteria and fungi on the severity of tomato early blight as well as fresh and dry weight (g/plant):

Tomato plants (cv. Super Strain B hybrid) were treated with two groups of antagonistic microorganisms under artificial infection with $A$. solani under greenhouse conditions. The first group included the antagonistic bacteria $(B$. megaterium, B. subtilis and Ps. fluorescens), while the second group contained the antagonistic fungi (T. harzianum, T. album and $T$. viride), Tomato plants were sprayed with these biological agents once each two weeks before infection with the pathogen (A. solani) and assessing tomato early blight disease severity and disease control efficiency, as well as measuring fresh and dry weight of tomato plants two weeks after infection by $A$. solani. The obtained results (Table, 3 ) show that when the plants were treated with T. harzianum and $T$. viride, this procedure recorded the lowest disease severity, being 15.42 and $19.56 \%$ with efficacy in controlling the disease reached to 71.60 and $63.97 \%$, respectively. The highest fresh and dry weight of tomato plants were also accompanied with the previously mentioned treatments by the two bio agents tested being, (4.05 and $0.95 \mathrm{~g} / \mathrm{plant})$ and (3.00 and 0.78 g/plant), respectively. Meanwhile, the antagonistic bacteria $B$. megaterium and $B$. subtilis, came next in controlling the disease and recorded 26.14 and $29.86 \%$ disease severity, and (51.86 and $54.00 \%$ efficacy), respectively. Also, these treatments recorded moderate weights for both fresh and dry weight of the tomato plants (2.84 and $0.74 \& 2.14$ and 0.66 g/plant), respectively. Treatment with either the antifungus T. album and the anti- bacterium $P S$. fluorescens showed the highest disease severity (34.56 and $31.30 \%)$ and the least disease control efficacy (36.35 and $42.53 \%$ ) respectively, as well as the lowest fresh and dry weight of the tomato plants with $(1.95$ and $0.33 \& 2.00$ and 0.25 (g/plant), respectively. In general, the results indicated that the fungal bio agent $T$. harzianum was the best one of all tested treatments in reducing the severity of tomato early blight, as well as increased fresh and dry weight of tomato plants. On the contrary, $T$. album was the least effective one in this regard.

2.1.2- The effectiveness of different concentrations of chitosan and salicylic acid on the severity of tomato early blight as well as fresh and dry weight (g/plant):

Results in Table (4) show that treatment of tomato plants (cv. Super Strain B hybrid), with different concentrations of the chemical inducers chitosan and salicylic acid, once every two weeks before infection with the pathogen $A$. solani, reduced the severity of tomato early blight in addition, increasing the fresh and dry weight of tomato plants under greenhouse conditions compared to untreated control. Chitosan at $4 \mathrm{mg} / \mathrm{mL}$ and salicylic acid at 25 $\mathrm{mM}$ were the superior inducer treatments which gave the lowest disease severity (12.16 and $17.18 \%$, respectively) and the highest disease control efficacy reached to 78.86 and $70.13 \%$, respectively. As well as the treatment recorded 
the highest fresh and dry weights of tomato plants that were increased and reached 6.60 and $0.99 \& 3.75$ and $0.66 \mathrm{~g} / \mathrm{plant}$, respectively. On the other hand, using both chemical inducers at the first concentration $(1 \mathrm{mg} / \mathrm{mL}$ and $1 \mathrm{mM}$, respectively) was the least effective inducer treatments in reducing disease severity and increasing fresh and dry weights of the tomato plants which recorded (30.52 and 35.18\%) disease severity and (46.94 and 38.84\%) disease control efficacy, respectively, as well as (2.43 and $0.45 \& 1.67$ and $0.40 \mathrm{~g} /$ plant respectively) for fresh and dry weights of the tomato plants. Generally, the chemical inducer chitosan was more superior in reducing disease severity of early blight and increasing the fresh and dry weights of tomato than salicylic acid.

Table (3): Effect of treating tomato plants with some antagonistic bacteria and fungi on the severity of tomato early blight as well as fresh and dry weight (g / plant) under greenhouse conditions.

\begin{tabular}{lcccc}
\hline \multicolumn{1}{c}{ Bio-agents } & $\begin{array}{c}\text { Disease } \\
\text { severity \% }\end{array}$ & Efficiency \% & $\begin{array}{c}\text { Fresh weight } \\
\text { (g/plant) }\end{array}$ & $\begin{array}{c}\text { Dry weight } \\
\text { (g/plant })\end{array}$ \\
\hline Bacillus megaterium & 26.14 & 51.86 & 2.84 & 0.74 \\
Bacillus subtilis & 29.86 & 45.00 & 2.14 & 0.66 \\
Pseudomonas fluorescens & 31.30 & 42.35 & 2.00 & 0.52 \\
Trichoderma harzianum & 15.42 & 71.60 & 4.05 & 0.95 \\
Trichoderma album & 34.56 & 36.35 & 1.95 & 0.33 \\
Trichoderma viride & 19.56 & 63.97 & 3.00 & 0.78 \\
Control & 54.30 & 0.00 & 1.19 & 0.12 \\
\hline LSD at 0.05 & 2.69 & & 1.01 & 0.25 \\
\hline
\end{tabular}

Table (4): Efficacy of different concentrations of chitosan and salicylic acid on the severity of tomato early blight as well as fresh and dry weights (g/plant) under greenhouse conditions.

\begin{tabular}{lccccc}
\hline $\begin{array}{c}\text { Chemical } \\
\text { inducers }\end{array}$ & Concentration & $\begin{array}{c}\text { Disease } \\
\text { severity } \%\end{array}$ & Efficiency \% & $\begin{array}{c}\text { Fresh weight } \\
\text { (g/plant) }\end{array}$ & $\begin{array}{c}\text { Dry weight } \\
\text { (g/plant) }\end{array}$ \\
\hline & 1.0 & 30.52 & 46.94 & 2.43 & 0.45 \\
Chitosan & 2.0 & 22.09 & 61.60 & 3.35 & 0.65 \\
$(\mathrm{mg} / \mathrm{mL})$ & 3.0 & 19.83 & 65.53 & 4.55 & 0.86 \\
& 4.0 & 12.16 & 78.86 & 6.60 & 0.99 \\
\hline & 1.0 & 35.18 & 38.84 & 1.67 & 0.40 \\
Salicylic acid & 5.0 & 27.92 & 51.46 & 2.35 & 0.45 \\
$(\mathrm{mM})$ & 10.0 & 24.02 & 58.24 & 3.00 & 0.57 \\
& 25.0 & 17.18 & 70.13 & 3.75 & 0.66 \\
\hline Control & & 57.53 & 0.00 & 1.11 & 0.25 \\
\hline LSD at 0.05 & 2.61 & & 0.17 & 0.11 \\
\hline
\end{tabular}

2.2- Estimation of enzyme activity and total phenols:

2.2.1-The effectiveness of the antagonistic bacteria and fungi on the oxidative enzyme's activity, hydrolysis enzyme and total phenols:

Results in Table (5) show that noticeable increases of oxidative enzymes activity, i.e., polyphenoloxidase (PPO) and peroxidase (PR) and hydrolysis enzyme chitinase as well as total dissolved phenols determined from leaves of tomato plants (cv. Super Strain B hybrid), artificially inoculated with $A$. solani, and treated with the antagonistic bacterial and fungal isolates (B. megaterium, B. subtilis and $P s$. fluorescens), and (T. harzianum, T. album and T. viride) before infection with $A$. solani, in vivo.

Concerning activity of oxidative enzyme, the highest increase in the activity of the three tested oxidative enzymes was observed in the leaves of tomato plants treated with $T$. harzianum and $T$. viride. Meanwhile, the lowest increase in the activity was obtained when tomato plants were treated with Ps. fluorescens and T. album.

The same trend i.e., increase the activity of chitinase enzyme in the leaves of tomato plants treated with both antagonistic bacterial and fungal isolates under the same conditions was 
also true (Table, 5). T. harzianum recorded the highest activity of chitinase, followed by $T$. viride. On the other hand, Ps. fluorescens recorded the lowest chitinase activity followed by $T$. album.

In regard to determination total dissolved phenols in leaves of treated tomato plants with the bio agents tested logical organisms, data shown in Table (5) illustrate that treated tomato plants with the antagonistic bacteria and fungi led to an increase in the total dissolved phenols compared to the untreated control. The highest significant increase in the total dissolved phenols in the tomato leaves was obtained from treated tomato plants with $T$. harzianum, by a greater amount than using any of the other bio agents, followed by T. viride (174.27 and 169.42 $\mathrm{mg} / 100 \mathrm{~g}$ fresh weight, respectively). However, the lowest value for total soluble phenols was obtained from leaves of tomato plants treated with Ps. fluorescens and T. album (95.52 and

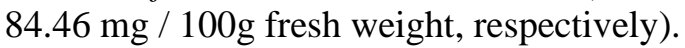

Table (5): Effectiveness of some antagonistic bacteria and fungi on polyphenol oxidase, peroxidase, hydrolysis enzyme (chitinase) and total soluble phenol content in tomato leaves artificially inoculated with Alternaria solani under greenhouse conditions.

\begin{tabular}{lcccc}
\hline \multicolumn{1}{c}{ Bio agents } & $\begin{array}{c}\text { Polyphenol } \\
\text { oxidase activity } \\
\text { (m/g f. w.) }\end{array}$ & $\begin{array}{c}\text { Peroxidase } \\
\text { activity } \\
\text { (m/g f. w.) }\end{array}$ & $\begin{array}{c}\text { Chitinase } \\
\text { activity } \\
\text { (m/g f. w.) }\end{array}$ & $\begin{array}{c}\text { Total phenol } \\
\text { (mg/100g f. w.) }\end{array}$ \\
\hline Bacillus megaterium & 2.14 & 3.52 & 3.53 & 148.72 \\
Bacillus subtilis & 1.79 & 2.87 & 2.49 & 136.54 \\
Pseudomonas fluorescens & 1.30 & 2.44 & 1.38 & 95.52 \\
Trichoderma harzianum & 4.38 & 6.43 & 5.93 & 174.27 \\
Trichoderma album & 0.83 & 1.98 & 1.02 & 84.46 \\
Trichoderma viride & 3.10 & 5.33 & 4.87 & 169.42 \\
Control & 0.39 & 0.69 & 0.52 & 62.83 \\
\hline Correlation coefficient & -0.75 & -0.76 & -0.84 & -0.89 \\
\hline
\end{tabular}

*f. $\mathrm{w} .=$ fresh weight

2.2.2- The effectiveness of different concentrations of chitosan and salicylic acid on the enzyme activity of oxidative and hydrolytic enzymes and total phenols:

Data illustrated in Table (6) show that treated tomato plants with different concentrations of chitosan and salicylic acid under greenhouse conditions before artificially inoculated by $A$. solani, exhibited an increase of oxidative enzyme activity i.e., polyphenoloxidase (PPO) and peroxidase (PR) and hydrolysis enzyme chitinase as well as total dissolved phenols in leaves of treated tomato plants compared to untreated control.

As for activity of oxidative enzymes, the highest increase in the activity of the two tested oxidative enzymes PPO and PR was observed in the leaves of tomato plants treated with chitosan at a concentration of $4 \mathrm{mg} / \mathrm{mL}$, followed by treatment of plants with salicylic acid at a concentration of $25 \mathrm{mM}(5.60$ and $3.90 \mathrm{~m} / \mathrm{g}$ fresh weight, respectively) compared to the rest of the other used concentrations for both of inducers. On the other hand, the lowest activity of both oxidative enzymes was obtained when plants were treated with $1 \mathrm{mg} / \mathrm{mL}$ and $1 \mathrm{mM}$ concentration of both chitosan and salicylic acid, 1.32 and $1.08 \mathrm{~m} / \mathrm{g}$ fresh weight, respectively.
The effectiveness of different concentrations of chitosan and salicylic acid on chitinase activity and total content of dissolved phenols observed in tomato plant leaves artificially inoculated by $A$. solani was studied under greenhouse conditions. The results in Table (6) also, show that when plants were treated with these different concentrations of both tested chemical inducers, this led to a significant increase in the activity of the enzyme chitinase as well as an increase in the total dissolved phenols compared to the untreated treatment. The highest increase in activity of chitinase, as well as the total dissolved phenols in the leaves of plants was observed by chitosan $4 \mathrm{mg} / \mathrm{mL}$ $(6.29 \mathrm{~m} / \mathrm{g}$ fresh weight), and $(125.85 \mathrm{mg} / 100 \mathrm{~g}$ fresh weight) respectively. Salicylic acid $25 \mathrm{mM}$ came the next one in increasing chitinase enzyme activity and total dissolved phenols in tomato leaves $(4.72 \mathrm{~m} / \mathrm{g}$ fresh weight) and (108.92 mg / 100g fresh weight) respectively. On the other side, the lowest value of chitinase enzyme activity as well as the total dissolved phenols was obtained in tomato leaves treated with the first concentration for each inducer, which recorded $1.29 \mathrm{mM} / \mathrm{g}$ fresh weight, and $74.97 \mathrm{mg} / 100 \mathrm{~g}$ fresh weight respectively. 
Table (6): Effectiveness of different concentrations of chitosan and salicylic acid on activity of polyphenoloxidase, peroxidase, hydrolysis enzyme (chitinase) and total soluble phenol content in tomato leaves artificially inoculated with Alternaria solani under greenhouse conditions.

\begin{tabular}{|c|c|c|c|c|c|c|c|c|c|}
\hline \multirow{2}{*}{$\begin{array}{l}\text { Biochemical } \\
\text { changes }\end{array}$} & \multicolumn{4}{|c|}{$\begin{array}{c}\text { Chitosan Concentration } \\
(\mathrm{mg} / \mathrm{mL})\end{array}$} & \multicolumn{4}{|c|}{$\begin{array}{l}\text { Salicylic acid Concentration } \\
(\mathrm{mM})\end{array}$} & \multirow{2}{*}{ Control } \\
\hline & 1.0 & 2.0 & 3.0 & 4.0 & 1.0 & 5.0 & 10.0 & 25.0 & \\
\hline $\begin{array}{l}\text { Polyphenoloxidase } \\
\text { (m/g f. w.) }\end{array}$ & 1.32 & 2.14 & 3.51 & 5.60 & 1.08 & 1.89 & 2.78 & 3.90 & 0.39 \\
\hline $\begin{array}{l}\text { Peroxidase } \\
\text { (m/g f. w.) }\end{array}$ & 2.80 & 3.07 & 5.47 & 6.43 & 1.44 & 1.87 & 3.64 & 4.40 & 0.69 \\
\hline $\begin{array}{l}\text { Chitinase } \\
\text { (m/g f. w.) }\end{array}$ & 2.39 & 3.52 & 4.87 & 6.29 & 1.29 & 2.46 & 3.61 & 4.72 & 0.52 \\
\hline $\begin{array}{l}\text { Total phenol } \\
\text { (mg/ 100g f. w.) }\end{array}$ & 87.75 & 97.87 & 101.84 & 125.85 & 74.97 & 89.76 & 92.64 & 108.92 & 62.83 \\
\hline
\end{tabular}

$*$ f. w. $=$ fresh weight

\section{DISCUSSION}

Tomato early blight, caused by Alternaria solani, is one of the most common leaf diseases in tomato plants, which causes damage to leaves, stems and fruits, causing severe damage to the plants, especially the aerial part, and reducing the size and number of fruits, which leads to significant economic losses in the yield, up to $79 \%$ (Sherf and MacNab, 1986 and Gwary and Nahunnaro, 1998). Agricultural pesticides have a clear and specific purpose that everyone knows. This purpose is to control insects and plant pathogens, including fungi and bacteria, as well as harmful weeds that harm agricultural crops, however, pesticides can negatively effect of some beneficial organisms. Therefore, it becomes necessary to develop environmentally friendly and biodegradable agricultural pesticides in order to control plant pathogens. Currently, biological control with antimicrobial organisms and resistance promoters offers a practical and economical alternative to control plant pathogens (Chandrashekara et al., 2012 and Sarhan, 2018). In this study, the effectiveness of bacterial agents (Bacillus megaterium, Bacillus subtilis and Pseudomonas fluorescens) and fungal agents (Trichoderma harzianum, Trichoderma album and Trichoderma viride), as well as the efficacy of different concentrations of the chemical inducers chitosan and salicylic acid, on Alternaria solani the causal pathogen of early blight of tomato, were evaluated under laboratory and greenhouse conditions. The results obtained in this study showed that all tested fungal and bacterial bio agents reduced linear growth of $A$. solani in vitro. The two antagonistic fungi $T$. harzianum followed by $T$. viride were the best fungal bio agents in reducing the linear growth of $A$. solani. However, the two antagonistic bacteria, $B$. megaterium and $B$. subtilis were the superior bacterial bio agents in this respect. These results are in agreement with the findings of EL-Tanany et al., (2018) who evaluated different isolates of Trichoderma and some bacterial bio agents on the linear growth of $A$. solani and stated that $T$. viride and $B$. subtilis were the best bio agents in reducing linear growth of $A$. solani. The obtained results showed that spraying of the aforementioned biological organisms on tomato plants before being infected with $A$. solani under greenhouse conditions, led to decrease the severity of tomato early blight, as well as increased fresh and dry weights of tomatoes compared to untreated treatment. These results are in agreement with the findings of EL-Tanany et al., (2018) and Moustafa et al. (2018a), they stated that using different isolates of Trichoderma and bacteria such as B. subtilis and Ps. fluorescens, as well as, biocides, Bio Zeid $2.5 \%$ powder (Trichoderma album $10 \times 10^{6}$ spore/g), and Bio Arc 6\% WP (Bacillus megaterium $25 \times 10^{6}$ cells/g), gave significant reduction in disease severity of early blight on tomatoes under greenhouse conditions. Antagonistic microorganisms play an important role in fighting plant diseases. They generally have a wide spectrum of action. Protective effect of the biological organisms includes different mechanisms like producing toxic substances that directly oppose the growth of pathogens (Leelasuphakul et al., 2008). It is known that fungi of the genus Trichoderma are effective in controlling pathogenic fungi through an antagonistic effect against the pathogen, by producing metabolites derived from cyclopentenone (George et al., 1977 and Strunz 
et al., 1977). Also, several authors explained the antifungal affectivity of fungi belonging to genus Trichoderma, this may be due to stimulation the anti-pathogen compounds or can wrap around the pathogen and form aspirin on its surface. Also, most of the antagonistic fungi produce many enzymes that degrade the pathogen's cell wall, and it may also produce antibiotics. (Handelsman and Parke, 1989; Schirmböck et al., 1994, Chet et al., 1998 and Inbar et al., 1998). While the bacterial bio agents $B$. megaterium, $B$. subtilis and $P$ s. fluorescens have more mode of action in controlling plant pathogens, the method of plant disease resistance relies on the production of the "megacin" metabolite that causes a radical change in the osmotic barrier of sensitive organisms by attacking the cytoplasmic membrane (Ivanovics et al., 1959 and Khalil et al., 2009). In addition, it acts as a catalyst for resistance, as it leads to an increase in polyphenols, as well as increasing the activity of defence-related enzymes peroxidase, chitinase, $\beta$-1,3-glucanase, and phenyl alanine ammonia lyase. On the other hand, they act as a growth promoter, able to dissolve phosphates, produce indole acetic acid (IAA), and siderophore (Chakraborty et al., 2006).

In our investigation, all the different concentrations of two the tested chemical inducers, i.e., chitosan and salicylic acid resulted a significant decrease in linear growth and spore germination of $A$. solani, in vitro. The chemical inducer chitosan at a $4 \mathrm{mg} / \mathrm{mL}$ followed by salicylic acid at $25 \mathrm{mM}$ were the most effective ones in reducing linear growth and spore germination of $A$. solani. Eid (2017) indicated that the use of sodium bicarbonate, potassium hydrogen carbonate, ascorbic acid, and salicylic acid, under laboratory conditions, reduced the linear growth of $A$. solani on PDA compared to the control treatment. In addition, when spraying tomato plants with different concentrations of chemical inducers chitosan and salicylic acid before the artificial infection with $A$. solani under greenhouse conditions reduced disease severity of early blight and increasing fresh and dry weight of tomato compared to control. In general chitosan was better than salicylic acid of the different tested concentrations in reducing disease severity and increasing the fresh and dry weight of the tomato plants. These results agree with the findings of Eid (2017) who found that treating tomato leaves with chitosan prior to inoculation with $A$. solani reduced leaf infection rates and disease index. Also, EL-Tanany et al.
(2018) and Moustafa et al. (2018b), reported that spraying tomato plants with tested chemical inducers, chitosan, and salicylic acid, prior to infection of tomato plants with the pathogen $A$. solani, was highly effective in controlling tomato early blight, under greenhouse conditions. The results obtained can be interpreted considering the findings reported by Katiyar et al. (2015), who stated that chitosan affects various physiological responses such as plant immunity and defense mechanisms involving different enzymes such as polyphenoloxidase, tyrosine ammonia lyase and antioxidant enzymes. It was also indicated that there is a link between stimulating plant resistance by chemical inducers and some biochemical changes in tomato leaves. In this regard treatment of tomato plants with chitosan led to an increase in the activity of peroxidase, polyphenoloxidase (catechol oxidase), phenylalanine ammonia-lyase, chitinase and 1,3glucanase in the leaves, but to different degrees depending on the cultivar. Also, a high percentage of phenols, which are indicative of the first stage of the defense mechanism, were recorded in the treated plant. Ahmed (2015) recorded a significant decrease in the incidence and severity of chocolate spot disease (\%) caused by the fungus Botrytis fabae in faba bean plants treated with bio-stimulants, and resulted an increase of chlorophyll, phenols, and flavonoids contents in faba bean leaves.

Regarding the chemical inducer, salicylic acid, the results obtained can be explained, in light of the findings of Spletzer and Enyedi (1999) who stated that salicylic acid (SA) is an important signaling molecule that plays an important role in plant defense against invading pathogens. In addition, the reaction of salicylic acid can be clarified in the fight against plant diseases, as many properties of this chemical inducer have been demonstrated, as it has been widely used in medicine as an analgesic, antipyretic and anti-inflammatory agent, in addition to its bactericidal, fungicidal effects as a protective property (Madan and Levitt, 2014). More recently, salicylic acid is used in agricultural operations as an alternative to fungicides, as a resistant catalyst (Wang et al., 2007) and a growth promoter (Sharma, 2013). El-Mohamedy et al., (2014) reported that when tomato plants were treated with $100 \mathrm{mM}$ salicylic acid, this treatment led to a significant increase in plant height as well as the branches number / plant. The stimulation of plant resistance may be explained by the chemical 
inducers of chitosan and salicylic acid, based on the studies of "omics", where it was recently suggested that the priming phenomenon be divided into three different phases. In the first stage, levels of different transcription, proteins, and metabolites are altered, making the plant an alert, however, in the post-challenge state, the primary anti-stress or induced state reactions (Alexandersson et al., 2016). All tested fungal and bacterial bio agents, as well as different concentrations of chemical inducers triggered some defense mechanisms in tomato plant leaves such as affecting the activity of oxidizing enzymes (peroxidase, polyphenoloxidase and hydrolytic enzymes (chitinase), as well as total phenols associated with activation the systemic resistance induction against pathogen infection A. solani, compared to untreated control.

From the obtained results, it was found that the tested antifungal $T$. harzianum and $T$. viride were more effective than bacterial isolates in reducing the severity of early blight on tomato plants, as well as increasing the activity of enzymes and total phenols. Regarding chemical inducers, the different concentrations of the chitosan followed by salicylic acid resulted an increase in the activity of oxidative and hydrolytic enzymes, as well as total phenols compared to control treatment, respectively. It can be concluded that the tested biological and chemical treatments stimulate the activity of (peroxidase and polyphenoloxidase) and hydrolytic enzymes (chitinase), as well as total phenols are associated with reducing the severity of early blight in tomato plants. In this study, great emphasis was placed on the interaction between disease severity and biochemical changes in leaves of tomato plants. The results showed that the tested isolates of the antagonistic organisms differed in their effect on disease severity and the activity of polyphenoloxidase, peroxidase, hydrolytic enzymes (chitinase) as well as the total dissolved phenols content in tomato leaves. In general, all the antagonistic organisms reduced the severity of early blight on tomato plants. Also, the negative relationship between the decrease of disease severity of early blight and increased activity of polyphenoloxidase, peroxidase and hydrolytic enzymes (chitinase), as well as an increase in total soluble phenolics, which is related to induction of induced systemic resistance activity in tomato plants, compared to the control treatment. The lowest disease severity as well as the highest increase in enzyme activity and total phenols content were recorded in tomato leaves when treated with $T$. harzianum and $T$. viride. These results were confirmed by the finding reported by ELTanany et al. (2018). The results obtained can be discussed in the light of the results indicated by (Ramamoorthy et al., 2002; El-Khallal, 2007; Latha et al., 2009; Abd-El-Khair et al., 2011 and Surekha et al., 2014), who reported the importance of using of Trichoderma spp., Bacillus spp., Pseudomonas spp. The action of these oxidative enzymes such as peroxidase and polyphenoloxidase has been explained, as they lead to enhanced formation of lignin and oxidation of phenols to more toxic quinones, while other oxidized phenols contribute to forming defence barriers to enhance cell structure as mentioned by Conti et al. (1974); Yamamoto and Tani (1978); Arora (1979). Gogoi et al. (2001); Ramamoorthy et al. (2002) and Anand et al. (2009b), found that the high enzymatic activity of oxidative enzymes (peroxidase, polyphenoloxidase) and hydrolytic enzyme (chitinase), leads to additional production and accumulation of phenols which may impede the spread of the pathogen from infected cells into healthy cells, and thus infection can be prevented or restricted. Also, Yoshida et al. (2003) reported that peroxidase plays an important role in ethylene biosynthesis, auxin regulation and plant cell wall components, i.e., lignin, suberin and wall thickening as part of the defense response to pathogens, especially fungi. Also, peroxides participate in the formation of lignin, the polymerization of glycoproteins rich in hydroxyproline, and the regulation of cell wall elongation. Several investigators explained the action of hydrolytic enzymes (chitinase) (Schlumbaum et al., 1986; Ham et al., 1991; Leah et al., 1991 and Velazhahan et al., 2003) they reported that analysis of chitin, which is a major component of fungal cell walls, which leads to direct inhibition of the growth of many fungi. On the other hand, the reaction of total phenols can be explained according to the findings of Guleria et al. (2005); Ali et al. (2007); El- Khallal (2007) and Abo-Elyousr et al. (2009), who showed that the accumulation of phenolic compounds at the site of infection as a result of treatment with antimicrobial organisms and chemical inducers was related to the restriction of pathogen development, because these compounds are toxic to pathogens. As for the interaction of phenolic compounds within plants (Abo-Elyousr et al., 2009), they indicated that many phenolic compounds have a function within the plant as 
anti-pathogens, as precursors to structural polymers such as lignin, or as signaling molecules. Also, these compounds may prevent the pathogen from progressing by increasing the mechanical plant cell wall strength.

\section{CONCLUSION}

It was concluded that the bio agent Trichoderma harzianum and the chemical inducer chitosan had a good effect on A. solani, the causative agent of tomato early blight, and could be a promising alternative to the use of chemical fungicides for controlling early blight disease of tomato, and it is better to use them for protection before infection catches.

\section{CONFLICTS OF INTEREST}

The authors declare no conflict of interest exists.

\section{REFERENCES}

Abbott, W.S. 1925. A method of computing the effectiveness of an insecticide. J. Econ. Entomol., 18: 265-267.

Abd-El-Khair, H.; Khalifa, R.M. and Haggag, K.H.E. 2011. Effect of Trichoderma species on damping-off diseases incidence, some plant enzymes activity and nutritional status of bean plants. Journal of American Science, 7(1): 156167.

Abd-El-Rahman, S.; Mazen, M.M.; Mohamed, H.I. and Mahmoud, N.M. 2012. Induction of defence related enzymes and phenolic compounds in lupin (Lupinus albus L.) and their effects on host resistance against Fusarium wilt. Eur. J. Plant Pathol., 134: 105116.

Abou-Elyousr, K.A.; Hashem, M.M. and Ali, E.H. 2009. Integrated control of cotton root rot disease by mixing fungal bio-control agents and resistance inducers. Crop Protection, 28: 295-301.

Ahmed, G.A. 2015. Efficiency of some bioinducers in induction of faba bean resistance to chocolate spot disease. International Journal of Scientific and Engineering Research, 11(6): 601-611.

Alexandersson, E.; Mulugeta, T.; Lankinen, A and Liljeroth, E. 2016. Plant resistance inducers against pathogens in Solanaceae species from molecular mechanisms to field application. Int. J. Mol. Sci., 17(10): 1673.

Ali, M.B.; Hahn, E.J. and Peak, K.Y. 2007. Methyl jasmonate and salicylic acid induced oxidative stress and accumulation of phenolics in Panax ginseng bioreactor root suspension culture. Molecules, 12: 607-621.
Ali, N.; Ramkissoon, A.; Ramsubhag, A. and Jayaraj, J. 2016. Ascophyllum extract application causes reduction of disease levels in field tomatoes grown in a tropical environment. Crop Protection, 83: 67-75.

Allam, A.I. and Hollis, P.J. 1972. Sulfide inhibition of oxidase in rice roots. Phytopathology, 62: 634-639.

Anand, R.; Kulothungan, S.; Karthika, S.; Sentila, R. and Bhuvaneswari, K. 2009a. Assay of chitinase and beta-1,3 glucanase in Gossypium hirsutum seedlings by Trichoderma spp. against Fusarium oxysporum. Int. J. Plant Sci., 4(1): 255- 258.

Anand, T.; Bhaskaran, R.; Raguchander, T.; Samiyappan, R.; Prakasam, V. and Gopalakrishnan, C. 2009b. Defence responses of chilli fruits to Colletotrichum capsici and Alternaria alternata. Biol. Plant, 53(3): 553559.

Anonymous, 2016. Tomato production facts around the world. HORTI BIZ, Tuinbouw Communicatie. Middel Broekweg, 3.

Arora, Y.K. 1979. Changes in the enzymes involved in polyphenol metabolism in mung bean infected with Rhizoctonia solani. Ph.D. thesis, Punjab Agric. Univ., Ludhiana (India), 92pp.

Atia, M.M.M. 2005. Induction of resistance to Alternaria leaf blight (Alternaria cucumerina) in melon plants by Dl-ß-amino-n-butyric acid. Zagazig J. Environmental Res., 6: 85-104.

Bargabus, R.L.; Zidack, N.K.; Sherwood, J.W and Jacobsen, B.J. 2002. Characterization of systemic resistance in sugar beet elicited by a nonpathogenic, phyllosphere-colonizing Bacillus mycoides, biological control agent. Physiol. Mol. Plant Pathol., 61: 289-298.

Barnett, H.L. and Hunter, B.B. 1987. Illustrated Genera of Imperfect Fungi. MacMillan Pub. Co., New York, U. S. A., 218 pp.

Basco, M.J.; Bisen, K.; Keswani, C. and Singh, H.B. 2017. Biological management of Fusarium wilt of tomato using bio fortified vermicompost. Guizhou Academy of Agricultural Sciences. Mycosphere Journal of Fungal Biology, 8(3): 467-483.

Carson, R. 1962. Silent Spring, A crest reprint Fawcett Publications, NC., Greenwich, Conn., pp 400.

Chaerani, R.; Remmelt, G.; Stem, P.; Roeland, E. and Voorrips, R.E. 2007. Assessment of early blight (Alternaria solani) resistance in tomato using a droplet inoculation method. Journal of General Plant Pathology, 96-103.

Chakraborty, U.; Chakraborty, B. and Basnet, M. 2006. Plant growth promotion and induction of resistance in Camellia sinensis by Bacillus megaterium. J. Basic Microbiol., 46: 186-195. 
Chandrashekara, K.N.; Manivannan, S.; Chandrashekara, C. and Chakravarthi, M. 2012. Biological control of plant diseases, chapter 10 in Eco-friendly Innovative Approaches in Plant Disease Management International Book Distributors Dehradun, Uttarakhand (India), pp 147-166.

Chet, I.; Benhamou, N. and Haran, S. 1998. In Trichoderma and Gliocladium. (eds Kubicek, C. P. and Harman, G. E.) Taylor and Francis, London, 2: 153-172.

ChunYan, L.; GuoRui, M. and WenYing, H. 2003. Induction effect of chitosan on suppression of tomato early blight and its physiological mechanism. Journal of Zhejiang University Agriculture and life sciences, 29(3): 280-286.

Conti, G.; Vagettim, F.A. and Bassi, M. 1974. Phenylalanine ammonia lyase and polyphenol oxidase activities correlated with necrogenesis in cauliflower mosaic virus infection. Actahytopathol. Acad. Sci. Hung., 9: 185-193.

Eid, A.M. 2017. Pathological studies on early blight disease of tomato and its control. M.Sc. Thesis, Fac. Agric., Moshtohor, Benha Univ., pp139.

El-Ghaouth, A.; Arul, J. and Ponnampalam, R. 1991. Use of chitosan coating to reduce water loss and maintain quality of cucumbers and bell pepper fruits. J. Food Process Preservation, 15: 359-368.

El-Khallal, S.M. 2007. Induction and modulation of resistance in tomato plants against Fusarium wilt disease by bio agent fungi (Arbuscular mycorrhiza) and/or hormonal elicitors (Jasmonic Acid\& Salicylic Acid): Changes in growth, some metabolic activities and endogenous hormones related to defence mechanism. Australian Journal of Basic and Applied Sciences, 1 (4): 691-705.

El-Mohamedy, R.S.R.; Abdel-Kareem, F.; Aydi Ben Abdallah, R. and Gueddes-Chahed, M. 2015. Variation in chitosan and salicylic acid efficacy towards soil-borne and air-borne fungi and their suppressive effect of tomato wilt Severity. J. Plant Pathol. Microbiol., 6(11): 325-357.

El-Mohamedy, S.R.; Riad, J.; Khiareddine, H. and Mejda-Remadi, D. 2014. Control of root rot diseases of tomato plants caused by Fusarium solani, Rhizoctonia solani and Sclerotium rolfsii using different chemical plant resistance inducers. Tunis. J. Plant Prot., 39: 2032-2033.

EL-Tanany, M.M.; Hafez, M.A.; Ahmed, G.A. and Abd El-Mageed, M.H. 2018. Efficiency of biotic and abiotic inducers for controlling tomato early blight disease. Middle East J. Agric. Res., 7(2): 650-670.

Esh, A.M.H.; Atia, M.M.M.; Tohamy, M.R.A. and Taghian, S. 2011. Systemic resistance in sugar beet eliciated by non-pathogenic, phyllospherecolonizing Bacillus pumilus and B. subtilus against the pathogen Cercospora beticola Sacc. J. Plant Prot. Path., Mansoura Univ., 2(1): 6783.

Fokkema, N.J. 1973. The role of saprophytic fungi in antagonism against Derchsleras or okaniana (Helminthosporium sativum) on agar plates and on rye leaves with pollen. Physiol. Plant Pathol., 3: 195-205.

George, M.; Wu-Yun, S.R. and Stillwell, M.A. 1977. Structure and synthesis of a new cyclopentenone derivative from Trichoderma album. Can. J. Chern., 55: 1610.

Gogoi, R.; Singh, D.V. and Srivastava, K.D. 2001. Phenols as a biochemical basis of resistance in wheat against Karnal bunt. Plant Pathol., 50: 470-476.

Govindappa, M.; Lokesh, S.; Rai, V.R., Nail, V.R. and Raju, S.G. 2010. Induction of systemic resistance and management of safflower Macrophomina phaseolina root rot disease by biocontrol agents. Arch. Phytopathol. Plant Prot., 43(1/3): 26-40.

Guleria, S.; Sohal, B.S. and Mann, A.P.S. 2005. Salicylic acid treatment and/or Erysiphe polygonal inoculation on phenylalanine ammonia-lyase and peroxidase content and accumulation of phenolics in pea leaves. J. Veg. Sci., 11: 71-80.

Gwary, D.M. and Nahunnaro, H. 1998. Epiphytotics of early blight of tomatoes in Northeastern Nigeria. Crop Prot., 17(8): 619624.

Hahlbrock, K. and Scheel, D. 1989. Physiology and molecular biology of phenylpropanoid metabolism. Annu. Rev. Plant Physiol. Plant Mol. Biol., 40: 347-369.

Ham, K.S.; Kauffmann, S.; Albersheim, P. and Darvill, A.G. 1991. Host-pathogen interactions. A soybean pathogenesis-related protein with $\beta$ 1,3-glucanase activity releases phytoalexin elicitor-active heat-stable fragments from fungal walls. Mol. Plant-Microbe Interact, 4: 545-552.

Handelsman, J. and Parke, J.I. 1989. Mechanisms in biocontrol of soilborne plant pathogens. In Kosuge, T. Nester E.W. (eds). Plant Microbial Interaction New York McGraw hill, 3: pp 2761.

Hsu, C.L.; Chen, W.; Weng, Y.M. and Tseng, C.Y. 2003. Chemical composition, physical properties and antioxidant activities of yam flours as affected by different drying methods. Food Chemistry, 83: 85-92.

Hussein, M.M.A.; Abo-Elyousr, K.A.M.; Hassan, M.A.H.; Hashem, M.; Hassan, E.A. and Alamri, S.A.M. 2018. Induction of defense mechanisms involved in disease resistance of 
onion blight disease caused by Botrytis allii. Egyptian Journal of Biological Pest Control, 28: 80 .

Inbar, M.; Doostdar, H.; Sonoda, R.M.; Leibee, G.L. and Mayer, R.T. 1998. Elicitors of plant defensive system reduce insect densities and disease incidence. J. Chem. New York, 24(1): 135-149.

Ivanovics, G.; Alfoldi, L and Nagy, E. 1959. Mode of action of Megacin. J. Gen. Microbial., 21: 51-60.

Katiyar, D.; Hemantaranjan, A. and Singh, B. 2015. Chitosan as a promising natural compound to enhance potential physiological responses in plant. Indian J. P1. Physiol., 20(1): 1-9.

Khalil, R.; Djadouni, F.; Elbahloul, Y. and Omar, S. 2009. The influence of cultural and physical conditions on the antimicrobial activity of bacteriocin produced by a newly isolated Bacillus megaterium 22 strain. African Journal of Food Science, 3: 11-22.

Latha, P.; Anand, T.; Ragupathi, N.; Prakasam, V. and Samiyappan, R. 2009. Antimicrobial activity of plant extracts and induction of systemic resistance in tomato plants by mixtures of PGPR strains and Zimmu leaf extract against Alternaria solani. Biol. Control, 50: 85-93.

Leah, R.; Tommerup, H.; Svendsen, I. and Mundy, J. 1991. Biochemical and molecular characterization of three barley seed proteins with antifungal properties. J. Biol. Chem., 266: 1564-1573.

Leelasuphakul, W.; Hemmanee, P. and Chuenchitt, S. 2008. Growth inhibitory properties of Bacillus subtilis strains and their metabolites against the green mold pathogen (Penicillium digitatum Sacc.) of citrus fruit. Postharvest Biol. Technol., 48: 113-121.

Madan, R.K. and Levitt, J. 2014. A review of toxicity from topical salicylic acid. J. Am. Acad. Dermatol., 70: 788-792.

Maxwell, D.P. and Batman, D.F. 1967. Changes in the activities of some oxidases in extracts of Rhizoctonia infection bean hypocotyle in relation to lesion nutrition. Phytopathology, 57(2): 132-136.

Moustafa, M.S.H.; ALkolaly, A.M.A. and ElDakar, H.A.M. 2018a. Impact of bio agents and organic acids on Alternaria solani, the causal organism of tomato early blight disease and their side effect assessment. Global Journal of Advanced Research, 5(7): 234-242.

Moustafa, M.S.H.; ALkolaly, A.M.A.; Mostafa, F.A. and El-Dakar, H.A.M. 2018b. Fungicidal effect of nano copper particles on Alternaria solani the causal organism of tomato early blight disease compared with other copper fungicides and their toxicity to experimental animals. IJSRM. Human, 10(2): 195-217.

MSTAT-C. 1991. A Software program for the design. management and analysis of agronomy. res. exp., Michigan State University, pp: 400.

Nair, K.R.S. and Ellingboe, A.H. 1962. Method of controlled inoculations with conidiospores of Erysiphe graminis var. tritici. Phytopathology, 52: 714.

Prajapati, H.N.; Panchal, R.K. and Patel, S.T. 2014. Efficacy of bio agents and biological interaction of Alternaria solani with phylloplane mycoflora of tomato. J. of Mycopathol. Res., 52: 81-86.

Rais, A.; Jabeen, Z.; Shair, F.; Hafeez, F.Y. and Hassan, M.N. 2017. Bacillus spp., a bio-control agent enhances the activity of antioxidant defense enzymes in rice against Pyricularia oryzae. PLoS One, 12(11): e0187412.

Ramamoorthy, V.; Raghuchander, T. and Samyappan, R. 2002. Induction of defence related proteins in tomato roots treated with Pseudomonas fluorescens Pf1 and Fusarium oxysporum f. sp. lycopersici. Plant and Soil, 239(1): 55-68.

Ramkissoon, A.; Francis, J.V.; Bowrin, J.; Ramjegathesh, R.; Ramsubhag, A. and Jayaraman, J. 2016. Bio-efficacy of a chitosanbased elicitor on Alternaria solani and Xanthomonas vesicatoria infections in tomato under tropical conditions. Ann. Appl. Biol., 169: 274-283.

Ried, J.D. and Ogryd-Ziak, D.M. 1981. Chitinase over producing mutant of Serratia marcescens. Appl. Environ. Microbiol., 41: 664-669.

Rodrigues, T.T.M.S.; Maffia, L.A.; Dhingra, O.D. and Mizubuti, E.S.G. 2010. In vitro production of conidia of Alternaria solani. Tropical Plant Pathology, 35(4): 203-212.

Saikia, R.; Singh, B.P.; Kumar, R. and Arora, D.K. 2005. Detection of pathogenesis related proteins chitinase and $\beta-1,3$ glucanase in induced chickpea. Curr. Sci., 89(4): 659-663.

Sarhan, E.A.D. 2018. Induction of induced systemic resistance in fodder beet (Beta vulgaris L.) to Cercospora leaf spot caused by (Cercospora beticola Sacc.). Egypt. J. of Phytopathol., 46(2): 39-59.

Sarhan, E.A.D.; El-Far, E.M.M. and Ebrahiem, A.M.Y. 2018. Systemic resistance in snap bean (Phaseolus vulgaris L.) elicited by some chemicals and biotic inducers against white mold disease caused by (Sclerotinia sclerotiorum). Egypt. J. of Phytopathol., 46(2): 61-84.

Schirmböck, M.; Lorito, M.; Wang, Y.L.; Hayes, A.; Risan-Atac, C.K.I.; Scala, F.; Harman, G.E. and Kubicek, C.P. 1994. Parallel formation and synergism of hydrolytic enzymes and peptaibol 
antibiotics, molecular mechanisms involved in the antagonistic action of Trichoderma harizianum against phytopathogenic fungi. Appl. Environ. Microbial., 60: 4364-4370.

Schlumbaum, A.; Mauch, F.; Vogeli, U. and Boller, T. 1986. Plant chitinases are potent inhibitors of fungal growth. Nature, 324: 365367.

Sharma, P. 2013. Salicylic acid: A novel plant growth regulator-role in physiological processes and abiotic stresses under changing environments, in climate change and plant abiotic stress tolerance. Journal of Bioscience and Bioengineering, 120(3): 308-313.

Sherf, A.F. and MacNab, A.A. 1986. Vegetable Diseases and Their Control. John Wiley and Sons, New York. 634-640.

Simonetti, E.; Carmona, M.A.; Scandiani, M.M.; Garcı'a, A.F.; Luque, A.G.; Correa, O.S. and Balestrasse, K.B. 2012. Evaluation of indigenous bacterial strains for biocontrol of the frogeye leaf spot of soybean caused by Cercospora sojina. Lett. Appl. Microbiol., 55(2): 170-173.

Singh, R.S. 1982. Plant Pathogens "The Fungi" Oxford and IBH Publishing Co. New Delhi, Bombay Calcutta, 443 pp.

Singh, U.P.; Sarma, B.K. and Singh, D.P. 2003. Effect of plant growth promoting rhizobacteria and culture filtrate of Sclerotium rolfesii on phenolic and salicylic acid contents in chickpea (Cicer arietinum). Curr Microbiol., 46: 131.

Slinkard, K. and Singleton, V.L. 1997. Total phenol analysis: automation and comparison with manual methods. American Journal of Enology and Viticulture, 28: 49-55.

Spletzer, M.E. and Enyedi, A.J. 1999. Salicylic acid induces resistance to Alternaria solani in hydroponically grown tomato. Phytopathology, 89(9):722-727

Strunz, G.; Ren, W.; Stillwell, M. and Valenta, Z. 1977. Structure and synthesis of a new cyclopentenone derivative from Trichoderma album. Can. J. Chem., 55: 2610-2612.

Surekha, C.; Neelapu, N.; Prasad, B.S. and Ganesh, S. 2014. Induction of defence enzymes and phenolic content by Trichoderma viride in Vigna mungo infested with Fusarium oxysporum and Alternaria alternata. Int. J. of Agric. Sci. and Res., 4: 31-40.

Townsend, G.R. and Heuberger, J.W. 1943. Methods for estimating losses caused by diseases in fungicides experiments. Plant Disease Reporter, 27: 340-343.

Tuzun, S.; Rao, M.N.; Vogli, U.L.; Schardl, C. and KU, J.A. 1989. Induced systemic resistance to blue mold, early induction and accumulation of 1, 3-gluconases chitinases and other pathogenesis-related proteins (b-proteins) in immunized tobacco. Phytopathology, 79: 979983.

Velazhahan, R.; Jayaraj, J.; Liang, G.H. and Muthukrishmam, S. 2003. Partial purification and N-terminal amino acid sequencing of a $(\beta$ 1, 3-glucanase from sorghum leaves. Biol Plant., 46: 29-33.

Wang, D.; Karolina, P.M.; Angela, H.C. and Dong, X. 2007. Salicylic acid inhibits pathogen growth in plants through repression of the auxin signaling pathway. Current Biology., 17: 1784-1790.

Yamamoto, H.H. and Tani, T. 1978. Peroxidase and polyphenol oxidase in relation to the crown rust resistance of oat leaves. Phytopathology Z., 91: 193-202.

Yasmin, S.; Zaka, A.; Imran, A.; Zahid, M.A.; Yousaf, S.; Rasul, G.; Arif, M. and Mirza, M.S. 2016. Plant growth promotion and suppression of bacterial leaf blight in rice by inoculated bacteria. PLoS One, 11: e01606.

Yoshida, K.; Kaothien, P.; Matsui, T.; Kawaoka, A. and Shinmyo, A. 2003. Molcular biology and application of plant peroxidase genes. Appl. Microbiol. Biotechnol., 60: 665-670. 